\title{
Effects of sulfur dioxide on wine made with sulfitic maceration
}

\author{
G.V. Jardim, L. Zigiotto, W. Machado, and Â.R. Marcon \\ Unipampa - Federal University of Pampa, Campus Dom Pedrito, Street Vinte Um de Abril, 80, CEP 96450-000, RS Brazil
}

\begin{abstract}
Sulfitic maceration is part of a technique used in large companies to store must through the superdosing of sulfur dioxide added after the destemming of the grapes. The objective of this study was to analyze the physico-chemical characteristics of the wines elaborated by sulfitic maceration. The study was conducted at the Federal University of Pampa (UNIPAMPA), Campus Dom Pedrito, RS, Brazil. Three vinifications (identified by treatments 1,2 and 3) were performed with 3 replicates each. The grapes used were the cultivar Alicante Bouschet. Treatment 1 underwent the same procedures as treatment 2, except for the dosage of $1400 \mathrm{mg} . \mathrm{L}^{-1}$ of added sulfur dioxide. The grapes were destemmed, crushed and macerated for 2 days and before fermentation started, the must was heated to remove $\mathrm{SO}_{2}$. In the treatment 3 a traditional maceration was carried out for 5 days. The physicochemical characteristics of the wines were analyzed by Fourier Transform Infrared Spectroscopy (FTIR) and the results were analyzed by statistical analysis of comparison of averages. The color intensity of treatment 2 showed no significant difference in relation to the treatment 3 , demonstrating that with 2 days of sulphitic maceration, occurs a color extraction similar to a traditional 5-day maceration.
\end{abstract}

\section{Introduction}

For large companies producing grape derivatives (juices, wines, distillates and etc.) the use of grapes that have low sanity and little maturation makes it possible to create a niche market where the prices of the products are more competitive, although it is necessary to maintain a certain quality. Large companies also need logistics for the processing of all raw materials, since the availability of tanks and equipment during the harvest is limited, because the grape harvest is concentrated in 3 months of the year. Thus, sulphite maceration appears as a technique that facilitates the relocation of equipment and utilization of grapes with undesired quality. The sulfitic maceration is a technique that uses after the destemming and crushing processes, the addition of high doses of sulfur dioxide (between 1000 and $2000 \mathrm{mg} . \mathrm{L}^{-1}$ of $\mathrm{SO}_{2}$ ). After the high dosage is made a short pre-fermentative maceration which we call "sulphite maceration" followed by the pressing. This technique promotes rapid extraction of phenolic compounds without starting alcoholic fermentation for the production of a red wine and also makes it possible to store the wort without the need of a cooling system. For further vinification or juice preparation, the sulphited must is passed through a desulfurizer (equipment with a vacuum or steam heat exchanger) whereby the sulfur dioxide is withdrawn and the product can then be destined for the desired purposes. As this technique uses very energetic processes such as $\mathrm{SO}_{2}$ overdosing and the heating process to eliminate it, the study aims to analyze the physico-chemical characteristics of the wine elaborated by sulfitic maceration, as well as to analyze the effects of sulfur dioxide, comparing it with a traditional maceration winemaking.

\subsection{Sulfur dioxide in the oenological industry}

Sulphur dioxide is used in the wine industry due to its efficiency and durability in wine preservation. Among its functions is the action against oxidation, and inhibition of microorganisms [1]. Adding high doses of sulfur dioxide requires stainless steel tanks for proper storage, as the product at high dosages becomes corrosive. However, due to desulfation, it is possible to decrease the $\mathrm{SO}_{2}$ dose of the final product.

\subsection{Phenolic compounds}

The red wines are thus named because of their coloration and their structure coming from the phenolic compounds, these are extracted mainly during the process of maceration, period in which the musts stays in contact with grape skin.

Their quantity also depends on the characteristic of each cultivar. Phenolic compounds as well as primary aroma molecules are accumulated during maturation and are mainly concentrated in the skin of the grape [2].

\section{3. "Alicante Bouschet"}

The cultivar "Alicante Bouschet" is a cultivar Vitis vinifera known for its coloration quite a tintory, is generally used in Brazil to add color in red wines.

\section{Materials and methods}

The vinifications of the study were elaborated in the experimental winery of the Federal University of Pampa (UNIPAMPA), Campus Dom Pedrito, located in the city of Dom Pedrito, State of Rio Grande do Sul, Brazil. The 
Table 1. Must: Total acidity, tartaric, malic and gluconic acid from the must. Treatments: 1 - control treatment, with prefermentative maceration of 2 days; 2 - sulfitic maceration of 2 days; 3 - traditional fermentative maceration for 5 days.

\begin{tabular}{|c|c|c|c|c|}
\hline Treatments & $\begin{array}{c}\text { Total } \\
\text { acidity }\end{array}$ & $\begin{array}{c}\text { Tartaric } \\
\text { acid }\end{array}$ & $\begin{array}{c}\text { Malic } \\
\text { acid }\end{array}$ & $\begin{array}{c}\text { Gluconic } \\
\text { acid }\end{array}$ \\
\hline 1 & $9.40 \mathrm{a}^{*}$ & $9.23 \mathrm{a}$ & $9.46 \mathrm{a}$ & $1.36 \mathrm{~b}$ \\
\hline 2 & $5.10 \mathrm{~b}$ & $2.26 \mathrm{~b}$ & $5.70 \mathrm{~b}$ & $5.13 \mathrm{a}$ \\
\hline 3 & $8.40 \mathrm{a}$ & $7.40 \mathrm{a}$ & $8.00 \mathrm{a}$ & $0.20 \mathrm{c}$ \\
\hline
\end{tabular}

*The letters correspond to the statistical difference, through the Tukey test at $5 \%$ probability.

cultivar "Alicante Bouschet" from a vineyard located in the wine region of the Gaúcha Campaign, on the border of Brazil and Uruguay, was used as the study model.

Three treatments were performed with 3 replicates, obtaining on average 6 liters of must for each repetition. The microvinifications were based on an average Brix of $15.4^{\circ}$ Brix, density of 1.0675 , total sugars $128.3 \mathrm{mg} . \mathrm{L}^{-1}$, $\mathrm{pH}$ of 3.23 and total acidity of $7.63 \mathrm{~g} . \mathrm{L}^{-1}$ tartaric acid. Treatment 1 , called control treatment, underwent the same procedures as treatment 2, except for the dosage of $1400 \mathrm{mg} . \mathrm{L}^{-1}$ of sulfur dioxide added in gaseous form. In these two treatments, the grapes were destemmed, crushed and macerated for 2 days, and before fermentation started, the musts underwent $\mathrm{SO}_{2}$ removal, this heating to simulate the desulphitation reached $100{ }^{\circ} \mathrm{C}$ and was done in the laboratory by an open system, the procedure reduced the initial volume of musts to $40 \%$ and therefore it was necessary to add distilled water to replace the evaporated volume and then start the fermentation. The warming decreased the total $\mathrm{SO}_{2}$ of wine from $1400 \mathrm{mg} . \mathrm{L}^{-1}$ to $100 \mathrm{mg} . \mathrm{L}^{-1}$, according to analysis done through the Gibertini equipments. In the treatment 3 a traditional vinification was carried out with 5 days of maceration during the beginning of the alcoholic fermentation.

For treatments 1 and 3 were added $50 \mathrm{mg} . \mathrm{L}^{-1}$ of $\mathrm{SO}_{2}$ in the pre-fermentative operations. In all treatments were added: 2 mL.HL ${ }^{-1}$ of Everzym Rouge enzyme; 20 g.HL ${ }^{-1}$ of Gesferm nutrient for yeasts; and due to low amount of sugar, were added $34 \mathrm{~g} . \mathrm{L}^{-1}$ sucrose. The commercial yeast used was 522 Saccharomyces cerevisiae and at the end of the fermentations, the physicochemical analyzes of the wines were performed using Fourier transform infrared spectroscopy (FTIR) and, from the results, analyzes of variance (ANOVA) and comparisons by the Tukey test at $5 \%$ probability.

\section{Results and discussion}

Physicochemical analyzes of the must were made before fermentation started, but on the same day, which means that the control (T1) and sulfite (T2) treatments had already undergone the heating process (desulphation simulation). It is possible to observe, according to Table 1, the lower total acidity, tartaric and malic acid in the sulphited wine must (T2), due to the influence of the acid compounds binding to $\mathrm{SO}_{2}$. Heating influenced the production of gluconic acid compared to treatment 3 (T3) that was not heated and only a traditional maceration was done. The significant difference in $\mathrm{T} 1$ in relation to $\mathrm{T} 2$ also
Table 2. Density and ${ }^{\circ}$ Brix of wine must and ethanol. Treatments: 1 - control treatment, with pre-fermentative maceration of 2 days; 2 - sulfitic maceration of 2 days; 3- traditional fermentative maceration for 5 days.

\begin{tabular}{|c|c|c|c|}
\hline Treatments & Density & ${ }^{\circ}$ Brix & Etanol \\
\hline 1 & $1.066 \mathrm{a}$ & $15.80 \mathrm{a}$ & $9.91 \mathrm{a}$ \\
\hline 2 & $1.063 \mathrm{a}$ & $14.76 \mathrm{a}$ & $10.29 \mathrm{a}$ \\
\hline 3 & $1.073 \mathrm{a}$ & $14.73 \mathrm{a}$ & $8.82 \mathrm{a}$ \\
\hline
\end{tabular}

*The letters correspond to the statistical difference, through the Tukey test at $5 \%$ probability.

Table 3. Ammonia and potassium from the must. Treatments: 1 - control treatment, with pre-fermentative maceration of 2 days; 2 - sulfitic maceration of 2 days; 3- traditional fermentative maceration for 5 days.

\begin{tabular}{|c|c|c|}
\hline Treatments & Ammonia & Potassium \\
\hline 1 & $90.66 \mathrm{a}$ & $1799.66 \mathrm{a}$ \\
\hline 2 & $5.0 \mathrm{~b}$ & $1349.66 \mathrm{~b}$ \\
\hline 3 & $87.66 \mathrm{a}$ & $1349.66 \mathrm{~b}$ \\
\hline
\end{tabular}

*The letters correspond to the statistical difference, through the Tukey test at $5 \%$ probability.

Table 4. Physicochemical analysis. Treatments: 1 - control treatment, with pre-fermentative maceration of 2 days; 2 - sulfitic maceration of 2 days; 3 - traditional fermentative maceration for 5 days.

\begin{tabular}{|c|c|c|c|c|c|c|}
\hline Tr* & $\begin{array}{c}\text { Total } \\
\text { acidity }\end{array}$ & pH & $\begin{array}{c}\text { Volatil } \\
\text { acidity }\end{array}$ & $\begin{array}{c}\text { Red. } \\
\text { Sugar }\end{array}$ & Glyc & Color \\
\hline 1 & $13.8 \mathrm{a}$ & $2.78 \mathrm{a}$ & $0.16 \mathrm{a}$ & $2.03 \mathrm{c}$ & $6.63 \mathrm{~b}$ & $1.68 \mathrm{~b}$ \\
\hline 2 & $9.53 \mathrm{~b}$ & $3.17 \mathrm{a}$ & $0.23 \mathrm{a}$ & $4.66 \mathrm{a}$ & $8.06 \mathrm{a}$ & $3.67 \mathrm{a}$ \\
\hline 3 & $11.76 \mathrm{ab}$ & $3.08 \mathrm{a}$ & $0.16 \mathrm{a}$ & $2.70 \mathrm{~b}$ & $6.70 \mathrm{~b}$ & $4.79 \mathrm{a}$ \\
\hline
\end{tabular}

*The letters correspond to the statistical difference, through the Tukey test at $5 \%$ probability. Total acidity (g. $\mathrm{L}^{-1}$ tartaric acid); Volatile acidity (g.L $\mathrm{L}^{-1}$ acetic acid); Glyc $=$ Glycogen $\left(\mathrm{g} . \mathrm{L}^{-1}\right) ;$ Color $=420 \mathrm{~nm}+520 \mathrm{~nm}+620 \mathrm{~nm}$.

demonstrates the influence of $\mathrm{SO}_{2}$ in high doses in the production of gluconic acid.

Among the applied treatments, there was no statistical influence for the variables of density and quantity of soluble solids expressed in ${ }^{\circ}$ Brix in the must, therefore there was no significant difference for the amount of ethanol produced in the wines as shown in Table 2.

However, when we observed the ammonia (Table 3), the amount of nitrogenous compounds that bound to $\mathrm{SO}_{2}$ directly influenced the availability of nutrients to the yeasts, which explains the fermentation interruption in T2, visible in the amount of residual sugar (Table 4).

Regarding the color intensity, the T2 does not present significant statistical difference in relation to the treatment 3 , demonstrating that with 2 days of sulfitic maceration a color extraction similar to that occurs in a traditional maceration of 5 days occurs. Anthocyanins, responsible for wine pigmentation, are compounds that bind to $\mathrm{SO}_{2}$ in search of stability [1]. Sulphur dioxide, according to $\mathrm{pH}$, influences the color percentage of anthocyanins [3].

Oenococcus oeni bacteria were not added for the malolactic fermentation, the wine was left in favorable temperature conditions after the alcoholic fermentation and the sterilization caused by the warming of the must and the $\mathrm{SO}_{2}$ overdose (in the case of T2) can be seen, even with no statistical difference, T3 with traditional maceration 
Table 5. Wine: Malic acid and latic acid. Treatments: 1 - control treatment, with pre-fermentative maceration of 2 days; 2 - sulfitic maceration of 2 days; 3 - traditional fermentative maceration for 5 days.

\begin{tabular}{|c|c|c|}
\hline Treatments & Malic acid & Latic acid \\
\hline 1 & $5.63 \mathrm{a}$ & $0.00 \mathrm{a}$ \\
\hline 2 & $3.3 \mathrm{~b}$ & $0.00 \mathrm{a}$ \\
\hline 3 & $4.7 \mathrm{a}$ & $0.06 \mathrm{a}$ \\
\hline
\end{tabular}

*The letters correspond to the statistical difference, through the Tukey test at $5 \%$ probability.

shows some onset of malolactic fermentation, whereas T1 and $\mathrm{T} 2$ do not (Table 5).

\section{Conclusions}

It can be concluded that $\mathrm{SO}_{2}$ overdosing combined with a 2-day pre-fermentative maceration extracts similar amounts of grape compounds compared to traditional maceration. Sulfitic maceration, besides helping to produce quality wines, due to the sanity state of the grape, can also contribute to wineries with few storage tanks, since it can reduce maceration by at least 3 days.

The authors thank the Salton Winery for the donation of the grapes and the must, as well as the winemaker Daiane A. Badalloti for her willingness to help us.

\section{References}

[1] B.W. Zoecklein, K.C. Fugelsang, B.H. Gump, F.S. Nury, Análisis y Producción de Vino (EA, 2001), p. 185

[2] P. Ribéreau-Gayon, D. Dubourdieu, B. Donèche, A. Lonvaud, Handbook of Enology: The Microbiology of Wine and Vinifications, 2nd edn. (EW, 2006), vol. 1, p. 246

[3] P. Ribéreau-Gayon, Y. Glories, A. Maujean, D. Dubourdieu, Handbook of Enology: The Chemistry of Wine Stabilization and Treatments, 2nd edn. (EW, 2006), vol. 2, p. 152 